Section Editor

Mitchell S.V. Elkind, MD, MS

Laura Sanapo, MD

Luca Bartolini, MD

Taeun Chang, MD

Gilbert Vezina, MD

Correspondence to

Dr. Sanapo:

Isanapo@childrensnational.org
Teaching NeuroImages:

\section{Giant fetal arachnoid cyst with favorable neurologic outcome}

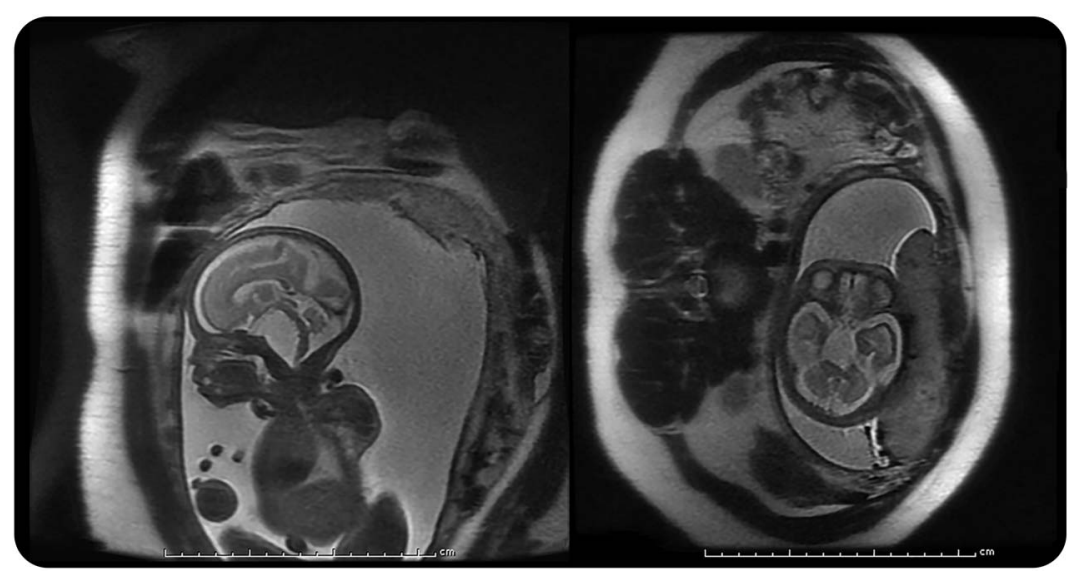

Sagittal midline single slice fast spin-echo T2 (Left) and axial single slice fast spin-echo T2 (Right) sequences show a large suprasellar-prepontine arachnoid cyst displacing the brainstem with asymmetric mass effect on the left side.

Figure 2 Postnatal brain MRI at age 11 months

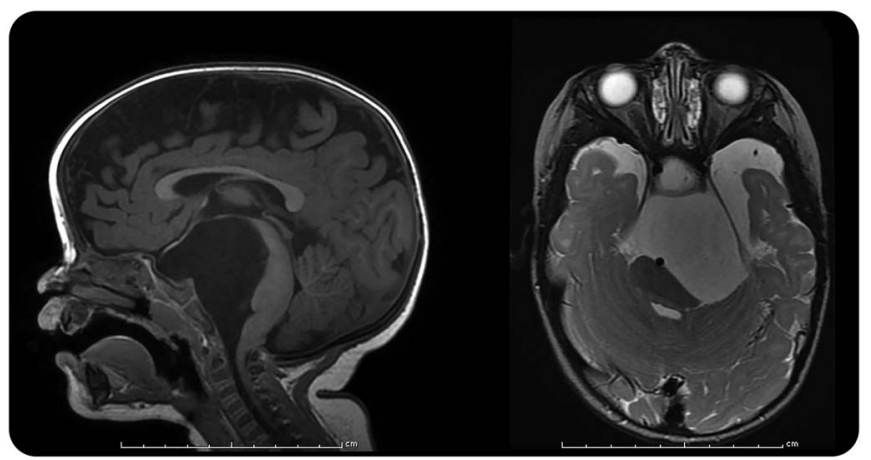

Sagittal midline T1 (Left) and axial fast spin-echo T2 (Right) sequences through the upper pons show a similar configuration of the cyst with interval enlargement.

A 29-year-old woman was referred after an ultrasound at 24 weeks' gestation demonstrated a $1.8-\mathrm{cm}$ intracranial cyst. Fetal $\mathrm{MRI}^{1}$ at 29 weeks (figure 1) showed a large cyst anterior to the brainstem measuring $3.4 \times 1.7$ $\mathrm{cm}$ with associated mass effect. Postnatal MRI at age 11 months (figure 2) confirmed the large suprasellarprepontine arachnoid cyst (SPAC) with mass effect on the brainstem. Neurologic examination at age 17 months revealed no gross neurodevelopmental deficits and no intervention was required. SPACs comprise $5 \%-12 \%$ of arachnoid cysts and are often symptomatic, with signs of hydrocephalus or mass effect, and may require surgery. ${ }^{2}$

\section{AUTHOR CONTRIBUTIONS}

Dr. Sanapo designed and drafted the article. Dr. Bartolini contributed to the design and drafting of the article. Dr. Chang contributed to the design of the article and reviewed the manuscript. Dr. Vezina contributed to the design of the article, reviewed the manuscript, and interpreted the fetal and postnatal MRI.
Download teaching slides: Neurology.org

From the Fetal Medicine Institute (L.S.), the Neonatal Neurology Program (T.C.), Department of Neurology (L.B.), and the Neuroradiology Program and Neuro MR, Division of Diagnostic Imaging and Radiology (G.V.), Children's National Health System, Washington, DC. Go to Neurology.org for full disclosures. Funding information and disclosures deemed relevant by the authors, if any, are provided at the end of the article. 
STUDY FUNDING

No targeted funding reported.

\section{DISCLOSURE}

L. Sanapo reports no disclosures relevant to the manuscript. L. Bartolini is a member of the editorial team, Resident \& Fellow Section, Neurology ${ }^{\circledR}$

T. Chang and G. Vezina report no disclosures relevant to the manuscript. Go to Neurology.org for full disclosures.

\section{REFERENCES}

1. Reddy UM, Abuhamad AZ, Levine D, Saade GR; Fetal Imaging Workshop Invited Participants. Fetal imaging: executive summary of a Joint Eunice Kennedy Shriver
National Institute of Child Health and Human Development, Society for Maternal-Fetal Medicine, American Institute of Ultrasound in Medicine, American College of Obstetricians and Gynecologists, American College of Radiology, Society for Pediatric Radiology, and Society of Radiologists in Ultrasound Fetal Imaging Workshop. Am J Obstet Gynecol 2014;210: 387-397.

2. Mattox A, Choi JD, Leith-Gray L, Grant GA, Adamson DC. Guidelines for the management of obstructive hydrocephalus from suprasellar-prepontine arachnoid cysts using endoscopic third ventriculocystocisternostomy. Surg Innov 2010;17:206-216. 


\section{Neurology}

Teaching NeuroImages: Giant fetal arachnoid cyst with favorable neurologic outcome Laura Sanapo, Luca Bartolini, Taeun Chang, et al.

Neurology 2015;84; e160-e161

DOI 10.1212/WNL.0000000000001596

This information is current as of May 18, 2015

$\begin{array}{ll}\begin{array}{l}\text { Updated Information \& } \\ \text { Services }\end{array} & \begin{array}{l}\text { including high resolution figures, can be found at: } \\ \text { http://n.neurology.org/content/84/20/e160.full }\end{array} \\ \text { Supplementary Material } & \begin{array}{l}\text { Supplementary material can be found at: } \\ \text { http://n.neurology.org/content/suppl/2015/05/16/WNL.0000000000001 } \\ 596 . D C 1\end{array} \\ & \text { This article cites } 2 \text { articles, } 0 \text { of which you can access for free at: } \\ \text { http://n.neurology.org/content/84/20/e160.full\#ref-list-1 } & \text { This article, along with others on similar topics, appears in the } \\ \text { References } & \text { following collection(s): } \\ \text { All Pediatric } & \text { http://n.neurology.org/cgi/collection/all_pediatric } \\ \text { MRI } & \text { http://n.neurology.org/cgi/collection/mri } \\ \text { Information about reproducing this article in parts (figures,tables) or in } & \\ \text { its entirety can be found online at: } & \text { http://www.neurology.org/about/about_the_journal\#permissions } \\ \text { Permissions \& Licensing } & \text { Information about ordering reprints can be found online: } \\ \text { http://n.neurology.org/subscribers/advertise }\end{array}$

Neurology ${ }^{\circledR}$ is the official journal of the American Academy of Neurology. Published continuously since 1951, it is now a weekly with 48 issues per year. Copyright () 2015 American Academy of Neurology. All rights reserved. Print ISSN: 0028-3878. Online ISSN: 1526-632X.

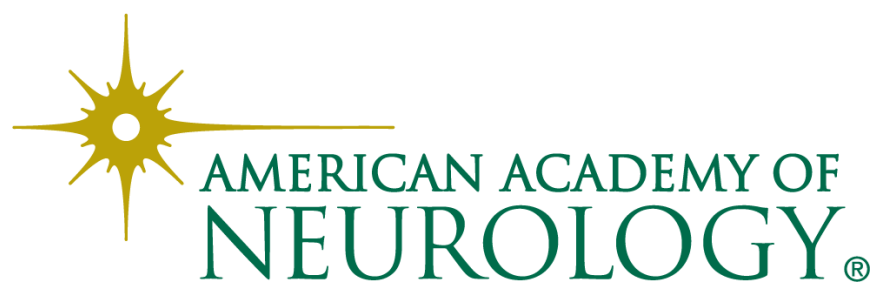

